\title{
Strategic partnering by EU firms: a rejoinder
}

(forthcoming in Journal of Common Market Studies, 2001

reply to Ramsay, H., Kay, N., and Hennart, J-F, Strategic Partnering by EU firms)

\section{Rajneesh Narula \\ University of Oslo}

My rejoinder to the paper by Ramsay et al in this Journal is not so much a rebuttal as a clarification. It is necessary to clarify that there is a difference between the various papers written jointly and individually by these scholars over the past decade (Kay 1991, Ramsay 1995, Kay, Hennart and Ramsay 1996), which I shall refer to as Kay and associates, and the Ramsay et al paper, which is a reply to the Narula (1999) article. I will make three related points.

First, I do not take issue with their earlier research findings per se, and indeed feel that our points of view are complementary. We have not presented diametrically opposite arguments, because we have dealt with two different -but overlapping - issues. Kay and associates focused on industrial collaboration in general. My paper (Narula 1999), on the other hand, studied strategic R\&D alliances, a subset of industrial collaboration. The reason that I did not directly challenge their perspective was because I did not (and still do not) feel that their analysis and conclusions (based on data on joint ventures and M\&A) were directly applicable to strategic R\&D alliances, or R\&D activity in general. However, Ramsay et al argues that their earlier findings can be so applied.

I also question their assumption that the single European market (SEM) increased the propensity of firms to use unilateral control in preference to alliances in the case $R \& D$. Such an argument implies that firms are in possession of all the resources they need, and undertake foreign market entry mainly in response to demand conditions. I will argue here that firms are rarely in possession of all the knowledge resources, and may seek to cooperate as a means to develop new assets or enhance existing ones.

My third point relates to policy. I do not agree with either Kay and associates or Ramsay et al in their indictment of EU policy. Both the framework programmes and the SEM need to be evaluated from the perspective of the competitiveness of EU firms. To do this, and to understand the decline in intra-EU collaboration, once must look to the broader issue of economic integration within globalisation. 
It is because of our different frames of reference that my 1999 contribution does not take the Kay and associates explanation as the starting point. My focus is different because, first, I have dealt with alliances that are strategic in nature. Second, I have dealt with alliances that have technological innovation as a primary objective. These alliances are fundamentally different from (say) marketing or manufacturing alliances (or joint ventures), because they tend to be short-term, and designed to address a specific problem. The work of Kay and associates is based on joint ventures and M\&A data which may or may not be either strategic or involve R\&D.

My understanding of inter-firm cooperation is that they tend to have both a costeconomising objective, and a strategic objective. The strategic motive implies that the objective is to improve the long term product-market positioning of at lest one of the firms involved, and are long-term profit optimising (Narula and Hagedoorn 1999). The MERITCATI database explicitly focuses on alliances where the motive is primarily (but not exclusively) strategic in nature. The reduction of costs is not always the primary concern in most R\&D alliances ${ }^{1}$, but the improvement of the value of the firm's assets ${ }^{2}$. Kay and associates do not make such a distinction, and implicitly take cost-economisation as the primary rationale behind industrial collaboration.

The basis for our disagreement stems partly from our use similar terminologies (e.g., inter-firm agreements, strategic activity), but with different underlying definitions. I take no umbrage with their predictions that they highlight both in their original paper(s) and their reply in this issue (pg 6). These predictions are, in their own words 'highly focused and precise', as long as the limitations of their data (and accompanying definitions) are kept in mind.

Extending their predictions to $\mathrm{R} \& \mathrm{D}$ alliances is also difficult given two assumptions that underlie the work of Kay and associates. First, that collaborative activity is a second-best alternative, with firms showing a stronger preference for either greenfield or M\&A wherever possible. There are several things wrong with this view. Market entry per se is not the only reason to undertake collaborative activity. Firms seek entry into foreign locations, inter alia, in response to supply-side factors, to access specific and specialised inputs not available

\footnotetext{
${ }^{1}$ Outsourcing agreements, on the other hand, have a larger cost-saving component. For a discussion see Narula (2001).

${ }^{2}$ This debate between the transaction cost and the organisational capability schools is succinctly presented in Madhok (1997).
} 
elsewhere (e.g., Dunning and Narula 1995, Florida 1997, Patel and Vega 1999). These resources are not necessarily available through the market, because they may be firm-specific. Thus, while the SEM may have allowed EU firms to achieve unilateral control over operations in other EU locations, Kay and associates assume that investing firms are in possession of all the necessary resources to do so. This applies to all aspects of value-adding, (inter alia sales and marketing) but especially to $\mathrm{R} \& \mathrm{D}$. Most products require multiple technological competences in a variety of different areas, and few firms can maintain in-house state-of-the-art expertise in every technological area that they may need (Granstand, Patel and Pavitt 1997, Narula 2001).

While it is true that firms engaged in asset-exploiting activities such as production or sales have a broader choice of options that include greenfield investments and licensing, some of these options are simply not available to firms that are seeking to undertake overseas R\&D. Arms-length transactions are not as effective, particularly in technology-intensive sectors or new, 'emerging' sectors, even if markets for these technologies were to exist. The further away these technologies are from commercial exploitation, the less likely that technology can be obtained through market mechanisms. Besides, its partly-public good nature prevents prospective selling firms from making technologies available for evaluation, and without doing so, the prospective buyer is unable to determine its worth.

Because of these factors, greenfield and M\&A are often impractical options when it comes to R\&D. R\&D in a new field begun from scratch involves high start-up costs, and considerable time. In fields where innovation is rapid, it may not provide a fast-enough response. Foolish is the firm that sells its $R \& D$ facilities while maintaining its production operations. From the buyer's perspective, the use of M\&A is also not attractive - as Kay (1997) acknowledges- when the complementary resources sought only cover a small area of the firm's interests. Even where a firm wishes to acquire a R\&D facility, it is generally not possible to do so, except in rare circumstances.

The second assumption I disagree with is that technology is easily transferable, such that to partner is to give one's technological knowledge away. This is simply not true, because knowledge has a tacit, user-specific element which makes it hard to efficiently transfer. Greater tacit and uncodified knowledge require closer, face-to-face interaction if it is to be successfully transferred (Cantwell and Santangelo 1999). Loss of technology is, nonetheless, a very real danger in any kind of cooperation. However, it is axiomatic that if this happened more often than not, EU firms would eventually severely curtail R\&D alliances with EU and non-EU firms alike. While it is true that there are many risks associated with partnering, the 
evidence points to a growing number of strategic $R \& D$ alliances ${ }^{3}$. This indicates to me that the rewards from partnering- on balance -outweigh the risks of technology loss, and that, in addition to a failure of markets, there is a failure of hierarchies (see Madhok 1997).

To put it succinctly, Kay and associates' analyses and predictions may well be accurate when comparing collaboration with unilateral control for industrial activity in general, but these explanations are not extendable to the special case of R\&D. The SEM project may have discouraged manufacturing collaboration, but I contend that it did not act as a brake on R\&D alliances. Furthermore, I believe that the framework programmes did in fact encourage some intra-EU cooperation where none might otherwise have occurred.

However, I also feel that by focusing on the role of the SEM and the framework programmes to encourage intra-EU collaboration and their apparent failure to sustain this activity is to confuse the means with the ends. My reading of EU policy is that intra-EU collaboration was seen as a means of reviving the competitiveness of EU high tech firms. The short sightedness of the Commission, if anything, was this: EU integration was (and remains) part of the much larger phenomenon of globalisation. In many ways, EU integration is a subprocess within globalisation, following de facto integration with de jure economic and political integration. In other words, the growth of cooperative agreements by EU firms illustrates the growth of alliance activity worldwide, with the SEM-related developments being somewhat secondary, reinforcing those due to the forces of globalisation. It is significant to note that the choice of alliance mode is determined by the technological characteristics of sectors of industry (Hagedoorn and Narula 1996). European R\&D alliances have demonstrated a similar tendency, and indeed, the fact that these patterns demonstrate industry-wide rather than national trends suggests that the same process of learning about the mechanics of alliance formation and management apply to all firms regardless of nationality. It also highlights the need of firms, again regardless of nationality, to partner with the most appropriate firms regardless of national origin (Narula and Hagedoorn 1999).

Firms do not seek simply to be competitive vis-à-vis their European rivals, rather they want to be competitive on a global scale, because markets and competition are increasingly global. This, in my reading, is what formed the core of the Kay and associates thesis, one that I (and most scholars) wholeheartedly agree with. Thus, ceteris paribus, European high-tech firms will prefer to seek partners who facilitate this objective. However, in the run-up to 1992

\footnotetext{
${ }^{3}$ ). It cannot be denied that cooperation can be a precursor to M\&A, but these are the exceptions, and not the rule. Indeed, Hagedoorn and Sadowski (1999) show that only $2.6 \%$ of R\&D alliances lead to M\&A.
} 
they were provided a 'window of opportunity' to rationalise their industries on a panEuropean level, through collaboration. Although I only have anecdotal evidence to support this (some of which I have cited in my 1999 article), firms utilised their pre-1992 alliances within the framework programmes to essentially collude and decide which sub-sectors within each industry they felt they could specialise in and be most competitive, relative to their European rivals. It did not harm matters that the Commission was willing to subsidise this activity, and turn a (temporary) blind eye to collusion. This explains both the 'bulge' in intraEuropean R\&D alliances in the latter part of the 1980s, and their subsequent decline thereafter.

My interpretation of the literature suggests that Kay and associates are probably right that this may not quite have been what the Commission had in mind, fully expecting the intraEU trend to continue well after 1993. However, I regard the objective of these policies to have been achieved, however unintended and coincidental. I do not consider the framework programmes to have been ineffective, or at least not as ineffective as Kay and associates imply. But it is early days yet, and our opinions at this stage are more a matter of conjecture than fact. The proof of the pudding, is, after all, in the eating. 


\section{References}

Cantwell, J. and Santangelo, G. (1999), 'The frontier of international technology networks; sourcing abroad the most highly tacit capabilities', Information Economics and Policy, pp 101-123

Dunning, J.H. and Narula, R. (1995) The R\&D activities of foreign firms in the United States. International Studies of Management \& Organization, 25 (1-2), 39-73.

Florida, Richard (1997) The globalisation of R\&D: results of a survey of foreign-affiliated R\&D laboratories in the USA, Research Policy, Vol 26, pp 85-103

Granstrand, O., Patel, P. and Pavitt, K. (1997) Multi-Technology Corporations: Why They Have "Distributed" Rather Than "Distinctive Core" Competencies, California Management Review, Vol. 39, pp 8-25

Hagedoorn, J. and Narula R. (1996) Choosing Modes of Governance For Strategic Technology Partnering: International and Sectoral Differences, Journal of International Business Studies Vol 27, pp 265-284

Hagedoorn, J. and Sadowski, B. (1999) The transition from strategic technology alliances to mergers and acquisitions: an exploratory study, Journal of Management Studies

Kay, N. (1991) Industrial collaborative activity and the completion of the internal market, Journal of Common Market Studies, Vol 29, pp 347-362

Kay, N. (1997) Pattern in Corporate Evolution, Oxford: Oxford University Press.

Kay, N., Ramsay, H., and Hennart, J-F. (1996) Industrial collaboration and the European internal market, Journal of Common Market Studies, Vol 34, pp 465-475

Madhok, A. (1997) Cost, value and foreign market entry mode: the transaction and the firm, Strategic Management Journal, Vol. 18, pp 39-61

Narula, R. (1999) Explaining Strategic R\&D alliances by European firms, Journal of Common Market Studies, Vol 37, no 4, 711-23 
Narula, R. (2001) Choosing between internal and non-internal R\&D activities: some technological and economic factors, Technology Analysis and Strategic Management, forthcoming

Narula, R. and Hagedoorn, J. (1999) Innovating through strategic alliances: moving towards international partnerships and contractual agreements, Technovation, Vol. 19, pp 283294.

Patel, P. and Vega, M. (1999) Patterns of internationalisation and corporate technology: location versus home country advantages' Research Policy, Vol 28, pp. 145-155 